\title{
Causation in the Corruption - Human Rights Relationship
}

\author{
Krista Nadakavukaren Schefer"
}

A. Introduction

I. Legal Attention to the Corruption

and Human Rights Problem........ 399

B. A Definition of Terms: Human Rights and Corruption....

I. Human Rights

II. Corruption .

1. Public Corruption .................. 404

2. Forms of Corruption............... 404

C. On Causation ....................... 405

I. Relevance of Causation to the study of Corruption and Human Rights... 405

II. Which Causation Analysis? General vs. Specific ........................ 406

III. Alternative Causation Analyses? ... 410

D. The Two-Way Relationship Between

Corruption and Human Rights ........ 411

I. The Conventional Wisdom: Corruption Causes Human Rights Violati-

ons ............................. 411

1. Corruption and Economic/Social Rights ...

2. Corruption and Civil/Political Rights...

II. Alternative Views .................. 413

1. Corruption's Effect on the Individual May be Positive 413
2. Corruption's Effect on a Disadvantaged Group May be Posi-

tive .......................... 414

3. Corruption's Effect as Overall Neutral ........................ 415

4. Other Voices ..................... 415

III. General Causation and Corruption-

Human Rights .................... 416

IV. Human Rights Impacts on Corrup-

tion ........................... 417

1. Hypothesis: Stronger Human Rights Protection Leads to Less Corruption................... 417

2. Which Human Rights Protections Lower Corruption?........ 418

a) Right to Information/ Free Press ....................... 418

b) Right to Democracy.......... 419

c) Economic Rights ........... 419

V. Anti-Corruption Efforts causing

Human Rights Violations ........... 420

E. Corruption - Human Rights and the WTO: Why Causation Matters ........ 421

II. Causation Analysis at Work: Making Human Rights a Trade Issue ....... 423

F. Conclusion ......................... 424

\section{A. Introduction}

Legal research is only beginning to address the complexities of the corruption and human rights relationship and my own research has found no explicit discussions of legal causation between the topics. Thus, the aim of the present paper is to illustrate that that taking up the topic of causation head-on is necessary for further progress in corruption-human rights legal research.

Given the highly visible relationship between corruption and human rights, perhaps it is not surprising that the specific question of causation has played only a modest role in the existing research. For anyone who has experienced life in a society with endemic corruption, it is difficult to deny that there is a connection between corruption and the violation of human rights. Given that apparent fact, parsing the relationship further seems of secondary importance: whether corruption leads to human

* Prof. Dr. Krista Nadakavukaren Schefer, J.D., Attorney at Law, ist SFN Förderprofessorin für Völkerrecht und Wirtschaftsvölkerrecht an der Universität Basel.

I would like to thank Franz Werro and Stephanie Leinhardt for their helpful advice and comments. The responsibility for any mistakes remains with me alone. 
rights violations or whether human rights violations lead to corruption, both are social wrongs and the more relevant question for lawyers and policymakers might seem to be one of determining how to address them simultaneously. ${ }^{1}$

Yet, the questions surrounding causation are far from purely theoretical. Besides being obviously critical to determinations of criminal responsibility, causation analyses may assume a great significance in explaining the correlation between high levels of corruption and human rights violations observed in certain systems, and in suggesting effective responses to corruption and to human rights violations. ${ }^{2}$

Determining whether causation exists (and in which direction it runs) between corruption and human rights is also critical when determining whether a particular institution should adopt measures to address either or both topics within its legal framework. The focus here will be on the World Trade Organization - an international economic institution with a mandate -----

When looking at what rules a state or an international organization should adopt to reduce corruption - whether for the ultimate purpose of improving human rights or for organizationally-specific goals - policymakers need to recognize that corruption and human rights interact in ways that exceed the one-way „but for” model that the law labels "Aequivalenz” causality (in Anglo-american law, „causation-in-fact”). Moreover, where Aequivalenz exists, policymakers looking at either improving human rights protection or reducing corruption may need to implement policies to control the other aspect if they want to be successful in achieving their goals. This holds for a finding of "Adäquanz"- (or, "proximate") causation as well, although the less direct the chain of causation, the more complex the legislative solution will have to be.

This paper does not pretend to present a complete systematic analysis of the causal linkages between human rights and corruption. For that, empirical data would need to be collected and analyzed - a task for a future paper, perhaps. Neither will the paper set out a new theory of causality that would be able to take into account multiple and reflective relationships between the social phenomena. Instead, this paper is aims only to provide other researchers with an impulse to pursue the overall

1 Not specifically addressing causation, one author, for example, writes the following on the topic of the human rights impacts of corruption: „We are not too clear which comes first, but when there is obvious ostentation in high public office, there is likely to be widespread corruption as well". M. Kiai, How Human Rights Principles \& Approaches Can Help in Fighting Corruption, HR/POL/GG/SEM/2006/ BP.2, at para. 8 (Paper presented at the United Nations Conference on Anti-Corruption Measures, Good Governance and Human Rights, Warsaw, 8-9 November 2006).

2 „Causation in the Law” Stan. Ency. of Philosophy (version of 12 August 2005). See E. Coupet, Jr., Investment and Corruption: A Look at Causality, J. of the Academy of Bus. and Econ. February 2003 (available at http://findarticles.com/p/articles/mi_m0OGT/is_2_1/ai_113563602/) (noting the use of causation-directed investigations into corruption and investment to economics and to policy makers). 
topic further by highlighting one particular example of where the study of causation could contribute to the pursuit of human dignity in a corruption-free world.

This article will proceed as follows. The rest of the present Section introduces the linking of corruption and human rights in legal scholarship, showing it to be relatively young. Section B presents the definitions of human rights and corruption used in this paper. While there are multiple views on the scope of either topic, I adopt a moderate definition for each in order to keep the choice of definition from becoming the focus of the article. Section $\mathrm{C}$ describes the concept of causation as addressed in the rest of the paper, warning that the ordinary private law norms may not be suitable for looking at relationships such as that between corruption and human rights. Section D sets forth the main findings described in the literature as to corruption's effects on human rights and human rights' effects on corruption. In Section E, the focus is on the implications that a finding of causation between human rights and corruption could mean to the World Trade Organization's (WTO) approach to human rights. Section F concludes.

\section{Legal Attention to the Corruption and Human Rights Problem}

It is no exaggeration to say that corruption is one of the most complex problems in legal research today. Crossing nearly all of law's comfortable specialization regimes, corruption is a problem for private law as well as public law, civil law as well as criminal law, and international law as well as municipal law. Moreover, the study of corruption implicates economic, social, and cultural dimensions in addition to the legal ones.

Until the 1990 s, the majority of studies of corruption were economically, politically, socially, or culturally based. Questions of how rent-seeking behaviors affected productivity, why certain regimes were more corrupt than others, how corruption at one level of society affected corruption at other levels, or how views of corruption vary among cultures are typical of these earlier studies of corruption. Corruption was examined as a phenomenon - an undesirable phenomenon for most - but one that's costs were societal, while the benefits were individual.

Into the $1990 \mathrm{~s}$, the few legal studies on corruption that were pursued were typically examinations of the criminal law aspects of corruption - attempts to parse the issues of defining the crime of corruption for legislative purposes, of enforcing the legal rules, of identifying evidence for prosecution, or of tracking down stolen assets. Corruption was examined as a technical legal matter, individualized to a particular case or legal instrument.

It was not until corruption's emergence as an issue of non-governmental organization (NGO) attention that human rights law perspectives on the topic began to appear. 
Founded in 1993, Transparency International (TI) was one of the first NGOs to research the impacts of corruption on the lives of citizens in highly corrupt regimes. TI field research pointed to the multiple dangers that corrupt decision-making can have on individuals and societies, from violating fundamental rights to physical security and non-discrimination, to denying rights to education and health, besides negating political rights to election of government officials. In fact, the relationship between corruption and fundamental political rights was seen as so close that the term "control of corruption” is one of six „dimensions” of a government's responsiveness to its citizens' needs and rights in the Worldwide Governance Indicator's project scheme. ${ }^{3}$ Similarly, the term "good governance" is frequently used to mean a low level of corruption.

The effects of corruption on economic indicators also attracted increasing attention in the $1990 \mathrm{~s}$. Business perceptions of highly corrupt governments correlated strongly with low levels of economic development, encouraging economists to study the correlation more closely. With studies that indicated a strong relationship between governance issues and a country's productivity (compared with a country's potential), international institutions aimed at supporting development became both a prime audience for NGO findings and an independent source of further research into corruption. The World Bank, International Monetary Fund (IMF), Organization for Economic Cooperation and Development (OECD), and numerous regional organizations have now adopted their own "good governance" programs to reduce corruption in hopes of fostering economic development. Under the good governance framework, the issues of corruption and human rights became clearly linked as policy matters. Of particular significance to the current paper is that it is the recognition of the corruption - human rights - development relationship that justifies putting both corruption and human rights on the international economic agenda.

Diplomatic attention to the connection between corruption and human rights heightened in the wake of the governance discussions in the early 2000 s. $^{4}$ The United Nations Convention Against Corruption 5 and the African Union's Convention on Combating and Preventing Corruption ${ }^{6}$ are among the most well known of the treaties stemming from those exchanges, and the United Nations continues to engage in

3 The Worldwide Governance Indicator's project is a collaborative project of the World Bank and the World Bank Institute (WBI). The 2009 indicators are set out in the WBI's News Release No. 2007/58/ DEC (available at http://siteresources.worldbank.org/ EXTWBIGOVANTCOR/Resources/Pressrelease_7-2009.pdf).

4 The Inter-American Covention Against Corruption was signed on 7 April 1996, but came into effect only on 7 April 2006; similarly, the Council of Europe Criminal and Civil Law Conventions on Corruption were negotiated and signed in the mid-1990 s, but came into effect in 2002 and 2003, respectively.

5 Adopted by UNGA Res. 58/4 of 31 October 2003 (in effect as of December 2005).

6 Adopted 11 July 2003 (in effect as of 2006). 
studies and conferences on aspects of the relationship between the human rights and corruption. ${ }^{7}$

Despite the economic and political interest in the corruption-human rights relationship, academic legal research on the human rights impacts of corruption is surprisingly recent. Significant interest has developed mainly within the last five years, but is increasing rapidly. Today human rights specialists around the world are undertaking examinations not just of corruption's impacts on human rights, but also the effects of anti-corruption campaigns on the rights of the individual and society's views of the pursuit of corrupt officials. ${ }^{8}$

\section{B. A Definition of Terms: Human Rights and Corruption}

\section{Human Rights}

The establishment of human rights law as an international legal discipline is one of the most significant results of the Post-World War II international law system. Building on the philosophical and natural law bases for recognizing individual rights developed over the centuries, current international law accepts that: "All human beings are born free and equal in dignity and rights"9, and takes from this premise that states have duties toward individuals by virtue of the subject's personhood. The law of human rights, then, is principally about the state-individual relationship, requiring the state to act or to refrain from acting so as to allow each individual to live a life of dignity. ${ }^{10}$ Beyond this basic definition, however, remains the question of how to determine what aspirations can be said to be a "human right". ${ }^{11}$ This is to a great extent an open question, leaving the specific definition of "human rights" highly contested.

There are clearly accepted human rights, of course, many of which are relevant to the study of corruption and human rights. The provisions of the International Covenant on Civil and Political Rights (ICCPR) guaranteeing the right to life, the right

7 See C. Mbonu, Corruption and its impact on the full enjoyment of human rights, in particular, economic, social and cultural rights (Preliminary Report of the Special Rapporteur) E/CN.4/Sub. 2/2004/23 (7 July 2004); United Nations Office of the High Commissioner for Human Rights, Background Note to the United Nations Conference on Anti-Corruption Measures, Good Governance and Human Rights, HR/POL/GG/SEM/2006/2 (2006) (explaining the content of a 2004 seminar and of the 2006 seminar organized by the OHCHR and the United Nations Development Program).

8 R. Saba, Corruption and Civil Rights: Warnings and Lessons from Human Rights Activism and Transitional Justice Experiences, expert summary from the United Nations Conference on Anti-Corruption Measures, Good Governance and Human Rights, HR/POL/GG/SEM/2006/BP.3 (Warsaw, 8-9 November 2006).

9 The Universal Declaration on Human Rights, Art. 1. The Universal Declaration, originally a nonbinding statement, is now widely accepted as customary international law.

10 The questions of responsibilties of non-state actors for human rights and of group rights are beyond the scope of the present work.

11 See generally Philip Alston, Conjuring Up New Human Rights: A Proposal for Quality Control, 78 Am. J. Int'l L. 607, 617-620 (1984) (urging that procedural - and not substantive - barriers be observed before a new proposal for a right is accepted as a human right). 
to liberty, the right to legal equality, the right to vote, and the right to be not subjected to torture are explicitly guaranteed by the State Parties. The provisions of the International Covenant on Economic, Social, and Cultural Rights (ICESCR), too, are positive law for treaty states, despite the questions as to the justiciability of many of the provisions. That Covenant's statements requiring states to strive to ensure the right to work, the right to an adequate standard of living, the right to health, and the right to education are as binding on the Parties as are any other treaty obligation. ${ }^{12}$ The provisions of the other five "core instruments" of human rights ${ }^{13}$ are similarly recognized as basic to the protection of "human rights", and are often what is thought of when the term 'human rights' is used.

The concept of human rights, however, is much broader than the core rights. Numerous non-binding norms, stemming from soft law instruments such as declarations and United Nations General Assembly (UNGA) Resolutions, for instance, are frequently discussed by commentators and promoted by human rights bodies as a part of "human rights law". The "right to development" is an example that is relevant to the present study. ${ }^{14}$ While this "right" has been declared by the African Charter on Human and Peoples' Rights in $1981^{15}$, the UNGA's Declaration on the Right to Development ${ }^{16}$, and the 1993 Vienna Declaration and Programme of Action ${ }^{17}$, as well as being taken up by a UN Working Group ${ }^{18}$, its legal nature as a human right

12 See generally, Committee on Economic, Social and Cultural Rights, General Comment No. 3 (1990), UN Doc.E/1991/23, Annex III. Paragraph 9 explains, "the raison d'être of the Covenant ... is to establish clear obligations for States parties in respect of the full realization of the rights in question. It thus imposes an obligation to move as expeditiously and effectively as possible towards that goal".

13 The seven core human rights treaties are: ICCPR, ICESCR, International Convention on the Elimination of All Forms of Racial Discrimination, Convention on the Elimination of All Forms of Discrimination against Women, Convention against Torture and other Cruel, Inmhuman or Degrading Treatment or Punishment, Convention on the Rights of the Child, and the International Convention on the Protection of the Rights of All Migrant Workers and Members of their Families. For a discussion of each of the core treaties, see Office of the High Commissioner for Human Rights, Fact Sheet No. 30: An Introduction to the Core Human Rights Treaties and the Treaty Bodies (text available at http:// www2.ohchr.org/english/bodies/docs/OHCHR-FactSheet30.pdf).

14 There are several excellent overviews of the right to development that include analyses of the right's legal development. See, e.g., Centre for Development and Human Rights, Right to Development: A Primer (Sage Publications: New Dehli, 2004); Laure-Hélène Piron, The Right to Development: A Review of the Current State of the Debate for the Department of International Development 7-14 (April 2002) (text available at http:www.odi.org.uk/resources/download/1562.pdf; last viewed 15 September 2010).

15 Article 22.1. The African Charter, also known as the Banjul Charter, was adopted 27 June 1981 and entered into force 21 October 1986. The text is available at 21 I.L.M. 58 (1982).

16 A/RES/41/128 (4 December 1986).

17 A/CONF.157/23 (12 July 1993) (paragraph 10 sets out the right to development as an "universal and inalienable right”).

18 The Commission on Human Rights established the Open-Ended Working Group on the Right to Development in its Resolution 1998/72, para. 10(a). 
is questioned. ${ }^{19}$ While some commentators would reject it from the category of human rights due to the non-bindingness of the instruments in which it is found, it certainly belongs to the "concept" of human rights if viewed from the point of view of influence on the international agenda. Another "emerging" human right is the right to democracy. ${ }^{20}$ Connected to the clearly binding human right to vote ${ }^{21}$, the right to democratic governance itself is based upon a combination of moral persuasiveness and practical experience rather than on its placement in a binding treaty. Such a norm, too, falls within the bounds of what can be considered a human right for the purposes of this paper.

Outside the circle of human rights lawyers, the definition of the just what "human rights" is becomes more unclear. The increasing body of normative work that would obligate states to uphold a veritable wish-list of attractive lifestyles may indeed contribute to the concept of 'human rights', yet will not be considered in this article. ${ }^{22}$ While such non-legal views of human rights can be effective in altering the evolution of the legal regime, they are not required for the arguments made here. Thus, neither calls for a "human right to corruption-free service" 23 nor for a recognition of corruption as a crime against humanity ${ }^{24}$ will be pursued.

\section{Corruption}

"Corruption" is often used as an accusation more than as a legal term with any precise meaning. Indeed, much of the debate surrounding the goal of eliminating corruption (that of what causes corruption, or how corruption affects development or human rights) revolves around the differences among authors as to what exactly counts as corruption.

For purposes of the following, the widely-accepted definition of corruption proposed by the World Bank is the basis: „The abuse of public office for private gain.” 25

19 See, e.g., Christian Tomuschat, Human Rights: Between Realism and Idealism 48 (Oxford/New York: Oxford Univ. Press, 2003). Part of the difficulty with accepting the right to development as a true human right is its description (by many of its adherents) as a "right to a process of development where all human rights - CPRs and ESCRs - are realised". Right to Development: A Primer, supra at 51.

20 See Thomas M. Franck, The Emerging Right to Democratic Governance, 86:1 Am. J. Int'l L. 46 (1992).

21 See ICCPR Art. 25(b).

22 For examples of such claims, see Alston, supra, at 610.

23 Raj Kumar, The Human Right to Corruption-Free Service: Some Constitutional and International Perspectives, 19:19 Frontline 14-27 September 2002 (available at http://www.thehinduonnet.com).

24 Suggestion by Kenyan Minister of Justice Kiraitu Murungi at the 11th International Anti-Corruption Conference in Seoul, Korea. See The Seoul Findings (Provisional), p. 1 (28 May 2003).

25 World Bank Group, Helping Countries Combat Corruption: The Role of the World Bank, Ch. 2, text accompanying footnote 1 (available at http://www1.worldbank.org/publicsector/anticorrupt/corruptn/cor02.htm). 


\section{Public Corruption}

The definition here, by focusing on the actions of those in „public office”, implicitly excludes private actions from its scope. Although the recently increasing attention to private-private corruption is bringing to light the destructive effects of that problem, ${ }^{26}$ this paper remains with the more limited state-centered view. This is for the sake of clarity: as governments are the primary bearers of human rights obligations, it is governmental corruption that is most likely to have impacts upon or be impacted by the protection of human rights.

The given definition includes the main forms of corruption that can occur by officials or other governmental employees: bribery; embezzlement and misappropriation; trading in influence and nepotism; and abuse of functions or position. ${ }^{27}$ Almost infinite in their variations, corrupt acts by officials can usually be classified into one of these groupings. A brief description of each of these types will suffice for my purposes.

One note before beginning the explanation of the various forms of corruption is in order: corruption and governance are separate concepts, despite their potential interactions. „Governance” describes the workings of the public system. As viewed by the World Bank, good governance is the „traditions and institutions by which authority in a country is exercised for the common good". ${ }^{28}$ Thus, planning, management, organization, accountability, transparency, and administrative qualifications are all aspects of governance. These are aspects of the design of the use of power and the implementation of that design. Corruption, on the other hand, is about misuse of power. While corruption can (and often does) lead to poor governance, good governance requires more than only the elimination of corruption - it requires capable individuals dedicated to serving the public as representatives of its interests. ${ }^{29}$

\section{Forms of Corruption}

Bribery is the acceptance of or demand for something of value in exchange for the performance of something illegal or for something that should not have been paid for. Bribery can occur at any level of government, may be isolated or endemic to the system, and may function as a (relatively) harmless transfer payment ${ }^{30}$ or as a serious

26 The United Nations Convention Against Corruption (UNCAC, or the Corruption Convention) includes a requirement that States "shall take measures to prevent corruption" in the private sector. See UNCAC, Annexed to GA Res. 58/4 of 31 October 2003, Article 12.

27 See UNCAC, Arts. 15-19. Article 20 of the Corruption Convention includes a suggestion that Parties criminalize ,illicit enrichment” as well. This crime, however, largely overlaps with the others, and for that reason is not listed separately here.

28 D. Kaufmann/A. C. Kraay/M. Mastruzzi, Governance Matters IV (2007).

29 M. Lewis/G. Pettersson, Governance in Health Care Delivery: Raising Performance, The World Bank Policy Research Working Paper 5074, at p. 3 (October 2009).

30 Bribery in this type of case is often referred to as „victimless”, as the parties to the crime are both benefited, despite the fact that the benefits cost something to the payor. 
abuse of human rights, depending on the specific case. Bribery is the conceptually easiest form of corruption to identify and condemn, as well as prosecute. Most studies of corruption focus on bribery, too, precisely because it is the easiest to recognize (and track). Despite bribery's high profile, when looking at the relationship between corruption and human rights, the other forms of corruption ought not be ignored.

Embezzlement and its counterpart, misappropriation, describe theft of governmental resources by officials. ${ }^{31}$ These forms of corruption can occur at any level, from the lowest employee to the highest official, and is often associated with procurement activities. Where infrastructure projects are overseen by corrupt officials, resource losses can be extreme.

Trading in influence and nepotism refer to the misuse of position to support relatives or friends. Although nepotism is sometimes obvious (as when government contracts are given to family members' companies), and often has negative impacts on the human rights system, it is particularly difficult to generalize the difference between nepotism as corruption and an employer's natural reaction to prefer to hire those known to him rather than a stranger. The adage that incompetence is not the same as corruption makes studying the impacts of nepotism particularly challenging.

Abuse of function is similar to the just-mentioned categories of corruption, but is broader in scope. Here, the official uses her status as a member of the government to benefit herself or hurt an opponent. Abuse of function can include legal actions, but ones that may be arbitrary or motivated by interests that are far removed from the public's welfare.

\section{On Causation}

\section{Relevance of Causation to the study of Corruption and Human Rights}

Any of the forms of corruption listed above can negatively impact upon the system of human rights law, as each denies the individual the right to non-discriminatory treatment. Indeed, on a systemic level, public corruption can function as a violation of the fundament of human rights itself by negating human dignity - the individual becomes valued by wealth or position rather than by inherent worth.

What is true about corruption's effects on human rights on a societal level is not necessarily true for individual cases, however. Disaggregating governmental corruption into individual acts may highlight different problems than the overall effects. Assume, for example, that a developer submits a tender for a government contract.

31 „Leakage” is the loss incurred from embezzlement/theft along a supply chain, resulting in a lack of supply of the intended resource available to the end user. See B. Gauthier/W. Wane, Leakage of Public Resources in the Health Sector: An Empirical Investigation of Chad, The World Bank Policy Research Working Paper No. 4351, p. 6 (September 2007) (defining leakage as „the proportion of resources intended for identified beneficiaries that does not reach them"). 
Although the tender may be the lowest price offer due to superior production efficiencies, assume further that the developer bribes the procurement official to secure the award of the contract. While such a bribe has a distinctly negative effect on the general state of the rule of law ${ }^{32}$, thereby negatively affecting the government's ability to carry out its obligations to respect, protect, and promote human rights for citizenry as a whole, there may not be any individual who suffers a violation of his fundamental human rights by virtue of such an act: on the facts as given, the competitors were not "harmed" because they would not have received the contract anyway; the value of the contract to the developer presumably offset the economic costs of the bribe; and the official, while unjustly enriched, cannot be said to have had her rights violated by accepting the offer of cash. To speak of causation between human rights and corruption, then, one must differentiate between the levels of obligations a state has to protect human rights and the types of causation. Therefore, before looking further at how these forms of corruption relate to human rights, it is appropriate to sketch out a view of causation itself and how it can alter the focus of the study.

\section{Which Causation Analysis? General vs. Specific}

The concept of causation that seems most likely to further the aims of this paper is one frequently used in U.S. tort law cases of injuries allegedly resulting from toxic contamination: general, or generic, causation as opposed to specific, or individual, causation. Unlike the usual private law analysis where liability is at issue, the main problem with toxic contamination cases is establishing the causation-in-fact, or "Aequivalenz" causation. Judge Winter's opinion in the Agent Orange case illustrates the concepts well:

"much ink has been spilled ... over the distinction between generic causation - whether Agent Orange is harmful at all, regardless of the degree or nature of exposure, and what ailments it may cause - and individual causation - whether a particular veteran suffers from a particular ailment as a result of exposure to Agent Orange....

"The generic causation issue has three possible outcomes: 1) exposure to Agent Orange always causes harm; 2) exposure to Agent Orange never causes harm; and 3) exposure to Agent Orange may or may not cause harm depending on the kind of exposure and perhaps on other factors." 33

32 United Nations Convention Against Corruption condemns corruption on this basis in its Preamble and commits Parties to "develop and implement or maintain ... anti-corruption policies that ... reflect the principles of the rule of law ...”. UN Convention Against Corruption, Article 5.1.

33 In Re “Agent Orange” Product Liability Litigation, 818 F.2 d 145, 164-165 (2nd Cir., 1987). 
The toxic tort issue is similar to the relationship between corruption and human rights when approached as a policy problem: the question is not one of liability whether a particular person should be held accountable for a particular injury - but rather whether there is sufficient evidence to assert that the type of injury that occurred could reasonably be said to have been caused by the type of action that took place. Only if there is such evidence of causation will policy-makers have a reason to address the independent factor. Given my object of illustrating the policy implications of determining the existence (and direction) of the corruption-human rights relationship, this seems a more suitable model than the more familiar "Aequivalenz-" (cause-in-fact), "Adäquanz-“ (proximate cause), or "Schutzzweck der Norm" (harm within the risk) theories that are used to determine (or limit) individual liability. ${ }^{34}$ My use of "causation", then, will refer to the general causation between groups of factors rather than between a particular event and an individual. ${ }^{35}$

This is not to imply that specific causation is unimportant to the study of corruption and human rights and its policy implications. For some purposes, specific causation is very important. When studying the relationships between legal regimes such as those of corruption and human rights, a detection of specific causation is often the first step in investigating the connection at all. Evidence of further instances of specific causation may then lead the way to the development of a concept of general causation by building upon probabilities. ${ }^{36}$ Thus, findings that embezzlement in a health ministry led to decreased access to medicine that in turn led to the death of an individual (who would have lived had he received the medication) may indicate that corruption „caused” (specifically) a violation of the individual's right to health. Several similar findings of specific causation can then lead to a claim that corruption "causes" (generally) violations of the human right to health.

In fact, much of the policy-oriented literature on corruption and human rights moves smoothly from specific causation analyses - describing particularly notable examples of bribery, fraud, or other such official behavior and indicating the monetary value of the losses to particular individuals or groups - to assertions of general causati-

34 A specific causation analysis would be useful, for example, to determine if an official accused of violating human rights could be prosecuted on the basis of corrupt acts leading to the violation.

35 This is a similar distinction to that of the predictive and explanatory notions of causation as opposed to the causation for purposes of attributing legal responsibility. See Antony Honoré, Causation and the Law, Stanford Encyclopedia of Philosophy, http://plato.stanford.edu/entries/causation-law/ (last visited 23 February 2010).

36 Honoré distinguishes the probability theory of causation from the so-called „philosophical” theory espoused by Mill. Honoré notes, however, that such a view is a „substitute for” true causation, used „when for practical or theoretical reasons it becomes impossible to state with precision the conditions of a certain type of event". A. M. Honoré, Causation and Remoteness of Damage, XI-7 Int'l Ency. Comp. L. at 29, s. 55 (Tübingen: J.C.B. Mohr, 1971). 
on. ${ }^{37}$ The latter allow for general observations to be made about structural dangers in the particular legal regime, and/or policy suggestions for stemming the opportunities for corruption based on the experience reported.

To be fair, it might seem that the nature of human rights as owed to an individual would make specific causation analyses particularly appropriate for examining corruption's effects on human rights. Problematic for our topic, however, is the fact that moving from specific examples of corruption causing human rights violations to a claim about the effects of corruption on human rights (or the other way around) presumes causation without investigating causation as a legal element. Predictability, rather than causation itself, seems to be the basis for such findings. This approach can be disputed on the theoretical level ${ }^{38}$ and is particularly problematic for policymaking, where there is no occasion to test the validity of the original claims of specific causation. ${ }^{39}$

More importantly for the law as policy, however, is the practical result of this confusion: because corruption and human rights are neither in a linear relationship nor are they factors that can be isolated from the overall context of social relations and economic realities, labeling one a "cause" of the other will often be legally inaccurate. Transposing suggestions on how to address the linkage through laws may, therefore, fail.

One example of the problems with assumed causation is that the corruption or human rights relationship is seldom uni-directional. Ackermann's comments on the relationship between corruption and economic growth illustrate the general problem of determining the direction of causation with regard to corruption:

„High perceived corruption and low growth rates are associated, but the causation can run from corruption to low growth or from low growth to corrup-

37 The recently published report by Transparency International and the International Council on Human Rights Policy is a good example of such analysis. See, Corruption and Human Rights: Making the Connection (Versoix, Switzerland: International Council on Human Rights Policy, 2009).

38 Compare M. Bunge, Causality and Modern Science 327 (4th rev'd ed.; Transaction Publ. - New Brunswick, NJ, 2009) („Unlike causation which is an ontological category, predictability is an epistemological category with an obviously historical status); with H. Feigl, explained by id. at 326, n. 12 and accompanying text (quoting Feigl, "'The clarified ... concept of causation is defined in terms of predictability according to a law ...'”).

39 The necessity of performing both the general and the specific causation analysis is stressed by courts. See Woodrow Sterling v Velsicol, 855 F.2 d 1188, 1200 (6 $6^{\text {th }}$ Cir., 1988):

"Although such generic and individual causation may appear to be inextricably intertwined, the procedural device of the class action permitted the court initially to assess the defendant's potential liability for its conduct without regard to the individual components of each plaintiff's injuries. However, from this point forward, it became the responsibility of each individual plaintiff to show that his or her specific injuries ... were proximately caused by ingestion or otherwise using the contaminated water. We cannot emphasize this point strongly enough because generalized proofs will not suffice to prove individual damages.” 
tion or, more likely, the causal arrow runs both ways, creating vicious or virtuous spirals". ${ }^{40}$

Economists have struggled to determine the direction of causation between corruption and growth through complex modeling, but the literature remains divided on the answer. ${ }^{41}$

With human rights, too, corruption can be either the cause or the result of violations. To return to the example used above, it is imaginable that the state had violated the rights of the health ministry employee by paying particularly low wages because the employee was of a disadvantaged ethnic group. The wage discrimination in turn „caused" the employee to steal medicines so as to be able to treat her own ill child. What causes what in this case? Although the death of the man was clearly a result of the violation of his right to medicine, it was a human rights violation in the first place that caused the corruption. While the recognized analyses of intervening causes could assist in determining the liability of the state as regards the death of the sick man, focussing on such causation will not further policy discussions on how to address the problems of the public health system. Moreover, assuming a general causation running only from corruption to human rights will fail to prevent further human rights violations of the sort suffered by the employee initially.

Another legal problem when talking of general causation between corruption and human rights is that of „'overtaking causes' or 'causal preemption”. ${ }^{42}$ Corruption and human rights violations may occur together, with neither general cause-in-fact nor specific causation, despite an appearance of both. It may be, for example, that in our case of medical theft, the embezzlement itself did not „cause” a violation of the right to health in fact because even if the medicine had been available, it would not have reached the patient who needed it due to a lack of distribution infrastructure. The human rights violation was thereby primarily caused by a failure of the state to ensure adequate roads or to pay a sufficient number of health workers rather than by the corrupt acts themselves. While there may be causation as per theories that permit the combination of causes, ${ }^{43}$ any general statements on causation arising from the situation would need to make such theoretical basis explicit.

40 S. Rose-Ackermann, Introduction and Overview in: S. Rose-Ackermann, ed., International Handbook on the Economics of Corruption xvi (Cheltenham, UK/Northampton, MA, USA: Edward Elgar, 2006).

41 See E. Coupet, Jr., Investment and Corruption: A Look at Causality, J. Acad. Bus. \& Econ. (Feb. 2003; available at http://findarticles.com/p/articles/mi_m0OGT/is_2_1/ ai_113563602/) (summarizing the economic literature on causation between investment and corruption and economic growth and corruption).

42 Honoré, (Fn. 19) at 3.1.

43 The NESS theory supported by Hart and Honoré, among others, permits single factors to be admitted as „causes” of a multi-factored occurrence. 


\section{Alternative Causation Analyses?}

Alternative analytical frameworks for causation may be better, but have not been applied to the particular corruption-human rights relationship. Legal sociology's analytical frameworks, for example, are similar to those of economists, suggesting that scholars approach causal analyses of law through an experimental strategy of "statistical third variable controls", in which the result of a particular law or action is determined through a process of incremental elimination of extraneous factors. ${ }^{44}$ Using techniques such as the creation of "experimental designs", "quasiexperiments", and "ex-post facto designs", lawyers can try to figure out the actual impacts a particular law or legal regime has on society even when there are multiple factors influencing the societal results. ${ }^{45}$ As set forth by Rottleuthner et al., the careful composition of the experiment (or quasi-experiment) is critical. ${ }^{46}$

Corruption's relationship with human rights, however, is particularly problematic in three ways that cast doubts on whether such sociological approaches to causation would be improvements to the more familiar causation analysis. First, rigorous experiments are difficult to perform because of the breadth of what is meant by "corruption" and "human rights". With such a range of possible causes and possible effects, designing experiments to control for third variables is going to be an extremely challenging exercise, and one open to significant criticism at every point, simply on the basis of the definition chosen. Moreover, the highly contextualized effects of corruption on human rights (and vice versa) will make the necessary comparison of the experiment's subjects particularly difficult. ${ }^{47}$ Second, the frequency with which feedback loops in any particular instance of corruption and a related human rights violation may appear will pose difficulties for controlled experiments. Third, and very significantly, analyses such as those suggested by sociologists and employed by economists rely on empirical data, which is difficult to obtain for human rights and extremely difficult to obtain for corruption. The illegality of the activity, the political brisance of the issue, and the financial impacts that revelations could have all contribute to making any collection of sufficient and reliable data difficult to the point of experimental failure.

44 See Hubert Rottleuthner and Margret Rottleuthner-Lutter, Rech und Kausalität 17-41, 23-4 in: Michelle Cottier, Josef Estermann, und Michael Wrase, eds., Wie Wirkt Recht? (Baden-Baden: Nomos, 2010).

45 Id. at 24-6.

46 Dependable results will rely on three conditions: (1) the existence of a control group and the experimental group; (2) a random assignment of subjects to each of the groups; and (3) an ability to adjust the independent factor. Id. At 24.

47 Rottleuthner notes that the difficulty of establishing random groups makes the social science method of causation analysis problematic for any area of law. Id at 25 . 


\section{The Two-Way Relationship Between Corruption and Human Rights}

Until recently, scholars have given relatively limited attention to analyzing corruption's effects on human rights. ${ }^{48}$ While much of the latest corruption-development research indirectly addresses human rights-related issues, most of the popular support for the anti-corruption efforts is rooted in traditionally competition-oriented ideals that focus on corruption's economic impacts on societies as a whole. ${ }^{49}$ The past several years, however, have witnessed an increasing awareness of corruption's impact on individuals (and disadvantaged groups), spurring activists and some scholars to pay direct attention to the effects of corruption on various civil, political, economic, and social rights. ${ }^{50}$

The following sets out the views of the relationship between corruption and human rights that are currently promoted in the literature. As stated above, there is virtually no analysis of causation itself in the literature. The findings tend to concentrate on determining Aquivalenz-causation rather than any other form, and do so through generalizing findings of specific causation. Given the policy-orientation of most works in this area, the significance lies not in the extent of liability, but whether there is a linear relationship between corruption and human rights at all. While there is much room for further theoretical inquiry, the available materials - mainly collected by non-lawyers - do not allow for more specific comment.

\section{The Conventional Wisdom: Corruption Causes Human Rights Violations}

Many writings on corruption and human rights perceive three main interactions between the two: corruption as a violation of human rights; corruption as causing human rights violations; and the methods used in the fight against corruption as a potential source of human rights violations. While the first of these is capsulized above, the second and third deserve fuller description.

The background paper to a United Nations-led seminar on corruption and human rights made the following comment:

„Corruption has an impact—partly through intermediary governance factors - on human rights in several ways. Human rights are indivisible and interde-

48 C. Raj Kumar, Corruption and Human Rights: Promoting Transparency in Governance and the Fundamental Right to Corruption-Free Service in India, 17 Colum. J. Asian L. 31, 51 (2003).

49 S. Rose-Ackerman's work on corruption is mainly looking at these aspects. See, S. Rose-Ackerman, ed., International Handbook on the Economics of Corruption (Cheltenham: Edward Elgar, 2006).

50 E.g., Kumar, Corruption (Fn. 17); J. Bacio Terracino, Hard Law Connections Between Corruption and Human Rights (Versoix, Switzerland: International Council on Human Rights Policy, 2007); International Council on Human Rights Policy/Transparency International, Corruption and Human Rights: Making the Connection (Versoix, Switzerland: International Council on Human Rights Policy, 2009); M. Sepulveda, Corruption and Human Rights: Integrating Human Rights into the Anti-Corruption Agenda: Challenges, Possibilities and Opportunities (Geneva: International Council on Human Rights Policy, Draft May 2010). 
pendent, and the consequences of corrupt governance are multiple and touch on all human rights." 51

While the paper continues by giving several examples of how corruption can harm human rights, the aim is not to examine the linkage itself, but rather to highlight how the two are related. Indeed, the evidence of corruption's general impacts on individuals is relatively clear: public corruption negatively affects the state's ability and willingness to uphold and protect the citizens' human rights. This affects both the adherence to human rights in general and the protection of particular human rights.

\section{Corruption and Economic/Social Rights}

The clearest evidence of corruption causing human rights violations can be traced in the impacts corruption has on economic and social rights. When corruption in the form of embezzlement drains state treasuries of financial resources, money available to support programs designed to secure human rights is reduced. This can affect the right to health, the right to education, and the right to a clean environment directly. Bribery, too, may lead to violations of such human rights: a number of sources report such violations as the result of corruption at the bureaucratic level and the level of ministry officials. When a doctor employed by the government refuses to treat a patient without being offered a supplement to the official charge, the patient's human rights are infringed. When a Minister of Environment supports a mining company's application to excavate in an area of significant biodiversity in return for a supplemental payment by the company's management, the populace suffers a violation of their right to a healthy environment. Similar scenarios can be imagined for the other forms of corruption and other economic/social rights. ${ }^{52}$

\section{Corruption and Civil/Political Rights}

Evidence of corruption's impacts on civil and political rights also indicates a strongly negative causal relationship. Where judicial officers and the police are complicit in corrupt activities, it is not only the individual's rights of access to justice and equality before the law that are denied, but the government might violate the human right to physical security. Nepotism in the engagement of civil servants can violate the right to equal access to public service if the friends or relatives an official hires are less (or even equally) qualified than unsuccessful applicants.

51 United Nations Conference on Anti-Corruption Measures, Good Governance and Human Rights, HR/ POL/GG/SEM/2006/2, para. 5 (Warsaw, 8 - 9 November 2006).

52 Kjaerum classifies corruption's impacts on human rights as institutional level impacts (when the strain on public finances results in too few resources to pursue the rights), population level impacts (when individuals are denied protection of their rights due to demands by corrupt officials), and judiciary level impacts (where violations of rights go unredressed due to corruption). M. Kjaerum, Breaking the Vicious Cycle: Corruption and Poverty; Obstacles to Social and Economic Rights. A Human Rights Based Bottom-Up Approach at 1 (paper delivered at the 12th International Anti-Corruption Conference, Guatelmala City and Antigua, Guatemala, 15-18 November 2006). 
Beyond this, corruption in governmental offices disconnects officials from their willingness to act as public servants for all equally, violating the right to equality and ultimately the right to democratic governance. Public officers who succumb to the temptation to use their position so as to extract profit may actively seek opportunities to extort money from constituents rather than seek to act in the best interests of the represented: legislators may vote on laws based on pleasing campaign contributors at the expense of the majority of their constituents; police may threaten fines or imprisonment solely to get illegal payments; safety officers may grant permits only to those companies who give them gifts, regardless of whether the official standards were complied with.

By reducing the effectiveness and legitimacy of the government as a whole, corruption limits any political rights held by the people as a society. ${ }^{53}$ Corruption in the courts hinders, where it does not completely prevent, the fulfillment of rights of individuals to a fair trial; corruption in the police force hinders, where it does not completely prevent, the rights of the individual to the presumption of innocence, and often to the right to be free from unjust detention. While large-scale corruption, for instance in government-funded construction projects, can threaten the lives and health of laborers and users of the bridges, roads, buildings, or other infrastructure due to ignored design failures or under-enforced safety standards, even petty corruption can push lower income families into poverty, with the accompanying denials of a wide range of human rights resulting from such a position. ${ }^{54}$ The more widespread the violations of such rights, the less the individuals in a society expect their government to function. No government that practices exceptional human rights protection can be considered to be upholding its international obligations. Corruption, viewed from this general causation perspective, does „cause” human rights violations.

\section{Alternative Views}

Despite the clearly negative societal impacts of corruption on human rights sketched out above, the conventional view of corruption „causing” human rights violations does not always hold. There are various angles to this finding that deserve mention.

\section{Corruption's Effect on the Individual May be Positive}

The first alternative view to the corruption-human rights violation causation narrative is that which claims that the effect of corruption on the lives of individuals even poor individuals - is not unambiguously negative. Though few, there do exist circumstances of truly positive contributions to the ability of particular persons to increase their enjoyment of human rights through corruption. As elaborated upon

53 See ICHRP/TI, Corruption and Human Rights: Making the Connection 35-45 (2009).

54 Id. at 65. 
in the Warioba Report, ${ }^{55}$ these circumstances include those instances in which a public employee illicitly supplements her insufficient salary with bribery payments in order to achieve a level of sustenance. Also referred to as a strategy of „income maintenance", 56 the ability to afford schooling or healthcare may depend on the taking of bribes. ${ }^{57}$

\section{Corruption's Effect on a Disadvantaged Group May be Positive}

Another situation of corruption promoting the human rights of particular individuals can occur when corrupt officials make policy decisions that benefit a disadvantaged sector of society. ${ }^{58}$ Even accepting the selfish intent of its maker, such policies may allow for a certain group to maintain its right to culture, its members' right to work, potentially even a group's right to food. Described as „political capture”, examples of such policies abound in the international economic law arena. ${ }^{59}$ Because economic policy changes always have both positive and negative impacts on a given group of citizens, the fact of corruption on the policymaking level cannot indicate whether or not the human rights of individuals are going to be protected or violated. Rather, the corruption may simply alter the distribution of the costs and benefits within the population. If, for instance, the maintenance of a source of illicit income through the

55 The Warioba Report is the common reference to the end result of an inquiry into the causes of corruption sponsored by President B. Mkapa of Tanzania. See Report of the Commission against Corruption Chaired by Hon. J. Warioba, State of Corruption in the Country (Dar es Salaam, December 1996).

56 G. Mutahaba, Pay Reform and Corruption in Tanzania's Public Service 14 (paper presented at the seminar on Potential for Public Service Pay Reform to Eradicate Corruption Among Civil Servants in Tanzania, 26 May 2005, Dar Es Salaam). Mr. Mutahaba elaborates upon four types of income maintenance strategies pursued by underpaid civil servants:

„Work sharing, where public service personnel agreed informally between themselves to share work loads to allow workers to pursue other income maintenance activities during official work time, ... Cost sharing; where public servants solicited payments directly from customers/clients before providing otherwise free services.

Revenue sharing, where revenue from formal user changes were misappropriated, mismanaged for individual gain; and

Resource sharing, where public resources, supplies and equipment were misappropriated, pilfered or mismanaged for individual gain.”

Id. at 5 .

57 See J. Bacio Terracino, Corruption and Human Rights 8, footnotes 26-29 and accompanying text (International Council on Human Rights Policy, 2007) (pointing out the corruption as a promoter of human rights angle of impact assessment with specific mention of the Warioba Report's explanation of some petty corruption as useful in allowing employees to „make ends meet”). The Warioba Report is the result of a study commissioned by the Tanzanian government in 1996 to evaluate public corruption. It was named after Prime Minister Joseph Warioba, who chaired the commission. See Report of the Commission Against Corruption Chaired by Hon. J. Warioba, State of Corruption in the Country (Dar Es Salaam, December 1996). But see P. M. Nichols/G. J. Siedel/M. Kasdin, Corruption as a Pan-Cultural Phenomenon: An Empirical Study in Countries at Opposite Ends of the Former Soviet Empire, 39 Texas Int'l L.J. 215, 223 (2004) (noting that the low salary „anecdote” is neither verified nor probable).

58 The same could be said for an official that grants benefits to a disadvantaged individual - for instance, a civil servant in a managing position hiring a mentally retarded relative to perform menial office tasks based on the fact that the relative otherwise would not be employed and the family needs money.

59 See K. Nadakavukaren Schefer, Corruption and the WTO Legal System, 43:4 J. World Trade 737 (2009). 
sale of import licenses provides the reason for a minister to oppose the elimination of a quantitative restriction on agricultural imports, and if such a policy prevents domestic farmers who otherwise would have lost a substantial portion of their income to no longer lose the income, the corruption itself has benefitted the farmers. While such a benefit is not to be confused with a protection of their human rights, the corruption at least indirectly prevented a denial of their human rights. In this case, discussion of causation between human rights and corruption is strained because of the complexities of determining the contours of how to characterize what the corruption actually caused: was the state's prevention of a denial of a human right the same as protection? how does one offset those protections with the clear fact that the embezzlement of state money by this official reduces the amount of money available to redistribute to the population as a whole?

\section{Corruption's Effect as Overall Neutral}

This brings me to the next angle on the corruption-human rights causation issue: there are numerous contexts in which corruption has an overall neutral effect on an affected society's human rights, too. This effect is due to a trade-off of rights. This may be the case where a person pays „speed money” to advance her position on a list to get medical attention. In any particular case, the corruption will benefit the one individual but inevitably slow the advance of another individual. Unless the briber requires immediate medical attention (which would not be available absent the bribe) and the non-briber does not, the bribe itself has not altered the human rights situation in any way: the government has neither violated nor promoted the human rights of either patient. Alternatively, where a foreign investor gives extra gifts to decisionmakers to gain market opportunities and such opportunities result in the creation of jobs for the local population, the diminution of the citizens' right to a fair political process may be balanced against the benefits to their economic right to work.

\section{Other Voices}

While the majority of commentators on corruption and human rights are concerned with the harmful effects of corruption on the protection of human rights, there are some voices who question this assumed causation. Prominent among this group is Professor Rajagopal, former officer with the United Nations High Commissioner for Human Rights in Cambodia. Writing in 1999, Rajagopal claims that the reported corruption-human rights causation is an artifact of a notion of legitimacy of the state that is rooted in Lockean liberalism. ${ }^{60}$ As such, the campaign to eradicate corruption is a "western" manipulation of human rights ideals to attack „eastern" practices. ${ }^{61}$

60 B. Rajagopal, Corruption, Legitimacy and Human Rights: the Dialectic of the Relationship, 14 Conn. J. Int'l L. 495, 501 (1999).

61 Id. at 502-506. 
Although Rajagopal's claims ultimately fail to persuade (not the least because of his ambiguous stance on the question of whether corruption should be acceptable), his point about unspoken assumptions shaping the thinking on causation is valuable. Causation analysis cannot escape normative underpinnings any more than prescriptions to break causal linkages can - at least when viewed in terms of particular relationships. ${ }^{62}$ Assertions that corruption causes violations of human rights presumes that corruption is "bad" (at least in a society where rule of law is broadly supported) and, implicitly, that human rights are „good”. If these normative presumptions were absent, the question of causation would be different. This might make it easier to approach, too, as it would be easier to objectively dissect the relationship.

An interesting experiment for the corruption-human rights causation project, then, would be a context in which corruption and human rights are seen as normatively neutral phenomena. Coming close to this „ideal” is the World Trade Organization (WTO). A brief examination of whether the WTO should address corruption or human rights is set forth below, highlighting the role that causation would play in deciding this question.

\section{General Causation and Corruption-Human Rights}

Despite the ambiguities and instances of a lack of specific causation between corruption and human rights, the conventional view of causation between corruption and human rights does seem to be accurate as an issue of general causation. Even in the most extreme case in which a particular instance of corruption supports a particular individual's right to life, the general causality between corruption and human rights is negative. This is so because the individual benefits that may arise from instances of corruption cannot be accurately viewed as fostering human rights. Based on the belief in the dignity of each person, adherence to human rights requires the state to treat each individual as an end rather than as a means to an end. Corruption denies such treatment, placing a higher value on the parties to the corruption than on those not party to it, while simultaneously using the payor as the payee's means to an interest. This constellation holds regardless of whether the payor offered the money or whether the payee demanded payment and, when the corruption is public, the State's involvement (through its agent or its resources) causes such a violation regardless of the form of corruption (bribes, embezzlement, etc.).

The general causation of corruption causing a violation of human rights law is even stronger. With the legal system of human rights aimed at upholding the dignity of individuals, the State is obligated to respect, protect and promote the de facto equa-

62 I disagree here with Stapleton, who argues that an „involvement” definition of causation is , untainted by normative controversies". Compare J. Stapleton, Causation in the Law, in: H. Beebee/C. Hitchcock/ P. Menzies, eds., The Oxford Handbook of Causation 744-69 (Oxford/New York: Oxford Univ. Press, 2009). 
lity of all under its authority. Corrupt practices are ultimately incompatible with principle of the equality of individuals and the responsibility of the state to ensure it. ${ }^{63}$ Whether by bribery, nepotism, or embezzlement, corruption damages the system of protecting human rights regardless of its actual effects on the life of a particular person.

\section{Human Rights Impacts on Corruption}

The finding of general causation between corruption and violations human rights explained above is not difficult to accept conceptually. There are other more problematic areas of corruption-human rights causation, however. As this is a study of the causation between corruption and human rights, it is important not to neglect the possibility of causation running from human rights to corruption. Can human rights violations lead to corruption? Can the protection of human rights reduce corruption? ${ }^{64}$ One might even ask whether there is evidence of a positive relationship between human right protection and levels of corruption.

\section{Hypothesis: Stronger Human Rights Protection Leads to Less Corruption}

The impact of human rights on corruption is another area of speculation, particularly for lawyers. This is so in part because there are few sources that address this question, and most of those looking at it are economists. ${ }^{65}$ Circumstantial evidence indicates that governments with stronger human rights protections are also less corrupt. ${ }^{66}$ Whether appearances reflect reality is not certain (due to the problems we face in both the corruption measurement area and the assessment of a government's adherence to human rights law), but it is plausible - at least on the general level. A government in which officials have less discretion in decisionmaking and more transparency in the rule-making process, one in which there is a formal dedication to the maintenance of human rights protections is less likely to be corrupt simply because there is less room for corruption to go undetected and will therefore (at least theoretically) lower the official's willingness to take the risk of engaging in corrupt behavior. Governments committed to human rights may also have officials with less

63 To Kurer, the principle of equality (or, in his words, „impartiality”) is the key to defining the term corruption. O. Kurer, Corruption: An Alternative Approach to its Definition and Measurement, 53 Political Studies 222 (2005).

64 Economic analysis of causation between investment and corruption led to a surprising finding of differences in the causation being detected between OECD and developing countries. While increased investment seemed to cause the level of corruption to decrease in developing countries, this finding did not hold for OECD economies. The author actually stated that developed countries should increase corruption if they wanted to achieve higher growth.

65 For an overview of the literature, see Nadakavukaren Schefer, Corruptin (Fn. 54) at 764-5.

66 M. Adil Khan/N. Chowdhury, Public Accountability, Corruption Control and Service Delivery: Governance Challenges and Future Options at 3 (text available at http://unpan1.un.org/intradoc/ groups/public/documents/un/unpan028466.pdf) (comparing auditing expenditures with governance scores, finding there to be strong correlation between higher expenditures on corruption-control and civil/political rights). 
willingness to engage in any activities that would violate human rights, even if they would be personally enriched by such actions.

Of course, the breadth of human rights law makes it difficult to generalize about the protection of particular rights and the effects of such protection on particular forms of corruption. Governments committed to promoting economic and social rights can be rife with corruption in the form of bribery and embezzlement. ${ }^{67}$ Indeed, the promotion of such rights is often a reason for high levels of public spending which, if not accompanied by active oversight, can be a major source of funds for corrupt officials. Even States with a strong record of protecting freedom of religion, assembly, and political activity can have high levels of nepotism and illicit enrichment by officials. ${ }^{68}$ Neither should a dedication to transparency throughout the administration be regarded as a shield against corruption. Transparency is a safeguard against corruption, certainly, but not an infallible one.

\section{Which Human Rights Protections Lower Corruption?}

The effects of a strong system of human rights protection in a state are likely to include a lowering of corruption, but there remains disagreement as to which human rights are significant to the reduction of corruption and which are endogenous.

\section{a) Right to Information/ Free Press}

Not surprisingly, several studies have shown that the rights of freedom of information and freedom of the press are of particular importance to reducing official misconduct. ${ }^{69}$ Where citizens are aware of what is occurring in government and can seek additional information on particular events or individuals in government, corrupt activities are more likely to be detected and, therefore, are less likely to occur. The correlation between information rights and corruption, however, has been disputed for contexts in which political freedoms are violated and is confused by factors such as a lack of competition among information sources. ${ }^{70}$

67 South Africa (4.7), China (3.6), India (3.4), and Venezuela (1.9), all of which have governments proclaiming the goal of social and economic equality, are also all regarded as significantly corrupt in international comparison. See Transparency International, Corruption Perception Index 2009 (a score of 10 on the CPI indicates no corruption while 0 indicates „highly corrupt”).

68 Italy is one of the few fully industrialized countries falling outside the top 50 of Transparency International's Corruption Perception Index, placing 63rd in 2009. India's governance, too, despite enjoying a vibrant democratic process, fails to qualify for the label „good”, with significant levels of corruption in all areas of public service. Id.

69 A. Adserà/C. Boix/M. Payne, Are You Being Served? Political Accountability and Quality of Government. IADP Working Paper 438 (2000) (daily newspapers); A. Brunetti/B. Weder, A Free Press is Bad News for Corruption, 87 J. Public Economics 1801 (2003) (freedom of information); M. Kaia, HR/ POL/GG/SEM/2006/BP.2, at para. 11 (access to information as key to fighting corruption).

70 D. Serra, Empirical Determinants of Corruption: A Sensitivity Analysis, 126(1) Public Choice, 225, 248 (2006); id. at 250 (does matter „under condition of political freedom”). 


\section{b) Right to Democracy}

Democracy's relationship to corruption is even more ambiguous. ${ }^{71}$ While it does seem to be a factor in affecting levels of corruption where democratic traditions have existed for an extended period of time, ${ }^{72}$ the direction of the causality of the relationship between higher democracy and lower corruption is ambiguous, as are the effects of the individual components of democratic governance. ${ }^{73}$ Moreover, perception indices often reflect the view that political parties - an integral part of functioning democracies - are the most corrupt institutions of government. ${ }^{74}$

\section{c) Economic Rights}

The ambiguity in data also appears when examining the protection of economic rights and corruption. While there are studies that support the intuition that higher wages for government employees reduce the level of corruption, other studies indicate an insignificant relationship in wages and corruption. Besides, it may be that more government involvement in the social sector increases official corruption by definition - if only by broadening the scope of the possible actors involved.

Clearly, further research needs to be done on the causal relationship between protecting human rights - civil and political as well as economic, social, and cultural and the level of corruption in a state. This is necessary for both specific and general causation analyses to be complete.

71 D. Treisman, The Causes of Corruption: a Cross-National Study, 76 Journal of Public Economics, 399-457, 438-439 (2000) („The fact that a country is democratic today makes just about no difference to how corrupt it is perceived to be"); Serra, Empirical Determinants (Fn. 48) at 250 (this correlation holds with certain sets of corruption data but not others).

72 Serra, Empirical Determinants (Fn. 48) at 248 (noting that the EBA reveals only a weak correlation between corruption and „actual democracy”, as opposed to the "highly significant” correlation for uninterrupted democracy and corruption reduction); Treisman, Causes of Corruption (Fn. 71) at 439 (,Those countries with at least 40 years of consecutive democracy behind them enjoyed a significant, though small, corruption dividend, and those with 20-30 years may also have benefited slightly").

73 A. A. Goldsmith, Slapping the Grasping Hand: Correlates of Political Corruption in Emerging Markets, 58:4 Am. J. Econ. and Sociology 865, 877 (1999) („,the coefficient for political freedom is not significant at conventional levels of confidence"). See also R. J. Gilson/C. J. Milhaupt, Economically Benevolent Dictators: Lessons for Developing Democracies (4 March 2010).

74 Corruption that induces policymakers to retain tariff legislation that protects a particular manufacturer (whether domestic or foreign) may distort the flow of goods and services such that consumers pay higher prices for lower quality goods - when such goods are necessities, the human rights impacts can be substantial, indeed, life-threatening. 


\section{Anti-Corruption Efforts causing Human Rights Violations}

Finally, there are additional concerns about the violation of human rights through anti-corruption efforts. ${ }^{75}$ Many of the concerns are procedural. The fight against corruption can lead to curtailments on pursued individuals' basic civil rights: from "specialized" investigative techniques that ignore rights of privacy (such as wiretapping $)^{76}$ to arbitrary arrests ${ }^{77}$ to adjusting the burden of proof away from the presumption of innocence. ${ }^{78}$ Whether such actions are justifiable in the undoubtedly difficult context of uncovering corruption is still a matter of debate between observers, and is the source of tension between the human rights and anti-corruption communities:

„There is a lasting suspicion in the human rights field that the anti-corruption fraction brush human rights concerns aside in the name of effectiveness; this concern is mirrored by the anti-corruption community, that tends to see human rights activists as obstructing their work with disproportionate sensitivity for the rights of the violators ...."79

This tension is thoughtfully reflected upon by Roberto Saba, who writes from his experiences with Argentina's anti-corruption campaign. Saba emphasizes that although anti-corruption campaigns do not have to violate human rights to be effective (they do need to be "inherently and structurally" a „threat to rights”), they may do so. ${ }^{80}$ Moreover, even when a campaign itself is not inherently violative, it is often implemented in a way so as to be violative of human rights. ${ }^{81}$ Governmental efforts

75 Kututwa sets forth a comprehensive overview of human rights that can be negatively affected by zealous anti-corruption actions. N. Kututwa, How to Combat Corruption While Respecting Human Rights, Working Paper presented at the International Council on Human Rights Policy Review Meeting: Corruption and Human Rights pp. 14-35 (Geneva, 28-29 July 2007) (setting out potential conflicts between the protection of human rights and anti-corruption campaigns, including warning against the use of torture during anti-corruption prosecutions). See also R. Saba, Corruption and Civil Rights: Warnings and Lessons from Human Rights Activism and Transitional Justice Experiences, HR/POL/GG/SEM/2006/BP.3 at para. 11-16 (listing freedom of expression, freedom of information, right to privacy, and due process as particularly threatened by anti-corruption campaigns).

76 Id. at 20-23 (generally looking at the relationship between protecting the defendant's right of privacy in a corruption investigation). See particularly id. at 21 (noting that Article 50 of the UN Convention Against Corruption authorizes the use of „special investigative techniques”, but makes them subject to national law; and recounting the European Court of Human Rights' case law on wire-tapping as a violation of the right of privacy).

77 Id. at 17-20 (setting forth the human right to liberty and cases in which anti-corruption efforts violated this right through unreasonable or arbitrary arrests).

78 L. Cockcroft, Corruption and Human Rights: a Crucial Link (Berlin: Transparency International, Working Paper 1998) (pointing out Hong Kong's legal struggle over the presumption of a defendant's guilt corruption cases); Kututwa, Combat Corruption (Fn. 75) at 6-13 (looking at the theory and caselaw relating to the reversal of the presumption of innocence in cases of corruption).

79 L. Koechlin, An Evaluation of National Integrity Systems (NIS) from a Human Rights Perspective (International Council on Human Rights Policy, 2007).

80 Saba, Corruption and Civil Rights (Fn. 75) at para. 8.

81 Id. 
are all too often exercises in political revenge: highly selective and discriminatory, limited to pursuing corrupt officials from the previous administration, and carried out with an eye on public opinion. ${ }^{82}$

Other criticisms of anti-corruption go further. The ideology of anti-corruption campaigns, stemming as they often do from the international financial institutions, is clearly based in liberal economics - the replacement of local distribution networks with transparent ones, non-discrimination, and privatization may be corruption-reducing, but they are also to the distinct benefit of foreign investors and traders. As such, anti-corruption's motivations change from being in the interest of society to being in the interest of the capitalist system. ${ }^{83}$

„Suddenly the effort to battle corruption becomes an effort to stigmatize some economic policies and some legal regimes at the expense of others precisely without analyzing their distributional or social consequences in any specific detail. It is in this sense that the anti-corruption campaign, even at its most reasonable core remains an ideological project, an effort to leverage the rhetorical advantages of a shared moral opprobrium for a series of specific legal or institutional changes without having to specify who will win and who will lose as a consequence". ${ }^{84}$

The corruption-human rights connection is lost as a motivation for ending corruption, negating the need for investigating the causation.

\section{E. Corruption - Human Rights and the WTO: Why Causation Matters}

While there is an intellectual case to be made that studies of the corruption-human rights relationship should give particular heed to causation, for the many policy purposes for which corruption-human rights studies are undertaken, a finding of general causation (whether or not such terminology is used) suffices. There are, however, certain issues that will require a more rigorous analysis. The following presents one example of how a determination of the existence (and direction) of causation can make the difference between having the mandate to address one or the other topic in its organizational rules and not having such a mandate. The example is that of the World Trade Organization (WTO), and the relevant question is whether or not it would have the institutional competence to take up policies promoting human rights, by virtue of human rights impacts on corruption.

82 Id.

83 D. Kennedy, The International Anti-Corruption Campaign, 14 Conn. J. Int'l L. 455, 464 (1999).

84 Id. at 465. 


\section{Overview of the WTO}

The WTO is the leading international organization regulating cross-border trade in goods and services. ${ }^{85}$ The institutional objective of the organization is to be the forum for coordinating the trade-liberalizing efforts of its Members. ${ }^{86}$ The legal provisions of the WTO commit Members to opening their markets and offering foreign traders equivalent conditions of competition both among each other (most favoured nation, or MFN, treatment) and vis-à-vis domestic traders (national treatment). ${ }^{87}$ These rules are enforced by a government-to-government dispute settlement mechanism that includes the possibility of imposing trade sanctions as a last-resort penalty for failure to comply with the trade laws. ${ }^{88}$

Given the institutional goals of liberalization and global economic growth, and what many economists have said about corruption's effects on economies, the WTO seems a likely candidate for developing anti-corruption rules. Corruption, after all, interferes with economic development: it slows growth and it prevents the theorized gains from trade from reaching the broader population when government officials use the gains from trade to satisfy their private wishes rather than the economic needs of their citizens.

Yet, the WTO remains steadfastly free of rules to directly control corruption. ${ }^{89}$ Suggestions of why this is so are set out fully elsewhere, but one of the asserted reasons is that corruption is not within the scope of the WTO's proper area of activities. ${ }^{90}$

The WTO Members also refuse to address the issue of human rights. Not only is there no movement to amend the treaties to provide explicit exceptions for protecting human rights, but neither is there sufficient support for beginning investigations on the relationship between trade and human rights under WTO auspices. Once again, the main reason for this stance is some Members' claim that human rights are not trade issues, and therefore, are outside of the competences of the Organization.

85 The WTO was established in 1995 as an international organization with legal personality. Marrakesh Agreement Establishing the World Trade Organization (hereinafter, WTO Agreement), Art. VIII. Members of the WTO may include states or governments possessing full political autonomy over their territory's import and export activities, as well as over internal rules governing market conditions. WTO Agreement, Art. XII.1. The inclusion of non-states as Members

86 WTO Agreement, Art. III.2.

87 The legal texts of the various WTO agreements are contained in the official collection The Results of the Uruguay Round of Multilateral Trade Negotiations (Cambridge: Cambridge Univ. Press, 2007) and are available on the WTO's website: www.wto.org. For a comprehensive overview of the WTO legal system, see Peter van den Bossche, Law and Policy of the World Trade Organization (Oxford: Oxford Univ. Press, 2009).

88 The rules on dispute settlement are set out in a separate agreement, the Understanding on Rules and Procedures Governing the Settlement of Disputes.

89 For an overview of provisions of the WTO agreements that indirectly address corruption, see Nadakavukaren Schefer, (Ftnt. 59).

90 Kenneth W. Abbott, Rule-Making in the WTO: Lessons from the Case of Bribery and Corruption, 4:2 J. Int'l Econ. L. 275 (2001). 
Placed in the light of the issue of causation between corruption and human rights, the denial of an institutional mandate to address either issue may seem to make further discussions irrelevant. Yet, adding in one other factor - trade liberalization - changes this conclusion. By triangulating the issues of corruption, human rights, and trade, we can see how critical a causation analysis is: a clear finding on causation could indicate whether or not the WTO really lacks a mandate for addressing the human rights conditions (or corruption) in Member territories. To be specific: given that the WTO has a clear mandate to "further the objectives" 91 of "raising standards of living, ensuring ... a large and steadily growing volume of real income..., and expanding ... trade in goods and services" ${ }^{92}$, and given substantial evidence that corruption can distort liberalization and slow growth, if it can be shown that human rights violations cause corruption, the WTO Members would have a reason to take up a program of promoting human rights. Similarly, if the protection of human rights can be shown to cause greater trade liberalization, and if a causation analysis would demonstrate that corruption violates those human rights, the WTO Members would have a reason to take up a program of corruption-prevention.

\section{Causation Analysis at Work: Making Human Rights a Trade Issue}

Corruption, as we have seen above, can be said to display a negative general causation to the protection of human rights. Its effects on the level of specific causation, however, are varied. The WTO is not directly concerned with the protection of human rights either at a general level or at a specific level. While the Organization makes a point of illustrating the human rights-enhancing potential of trade liberalization, the legal provisions of the WTO do not require Members to respect or protect human rights, much less promote them. The result is that even if corruption could be shown to „cause" human right violations, this would not provide a reason to the WTO to enact provisions requiring Members to take steps to eliminate corruption in their trade administration systems. Because the WTO has no organizational mandate to protect human rights, the protection of human rights - in and of themselves - cannot be a reason to take on the task of controlling corruption.

But human rights violations are not the only side effects of corruption. Corruption can also distort the creation and administration of trade regulations. Markets may not be opened because of corrupt elements in the government; traders may need to expect discriminatory treatment because of corruption; health or technical standards may be imposed to foster the illicit gains of key officials rather than for the public good. ${ }^{93}$ If these effects could be shown to be caused by corruption (under any ap-

91 WTO Agreement, Article III.1.

92 WTO Agreement, Preamble.

93 See Nadakavukaren Schefer, (Ftnt. 59) at 764-5. 
propriate causation analysis), the WTO would have an organization reason to try to control corruption in its Members' administrations.

This analysis goes further when the human rights regime is added: if there sufficient evidence of negative general causation between human rights protection and levels of corruption in trade administration, the WTO should foster not only corruptionreduction measures, but also human rights-protecting ones. (If specific causation could be demonstrated, one could also posit that the WTO should permit its dispute settlement mechanism to provide for enforcement of the obligation to reducing corruption among trade officials.) Such a policy of protecting human rights would be instrumental and necessarily narrow. The human rights protections that would concern the WTO would only be those that have a causal relationship to types of corruption that negatively influence trade policy makers. This would necessarily leave many, perhaps most, human rights outside of the WTO system's scope. But it would counter those Members and organizational voices that claim there is no scope for human rights in a trade body.

In the case of an organization that looks to a goal that is not corruption or human rights, but whose goal is clearly impacted by one of the two, it is the element of causation that gives a legitimate reason to address one or the other, thereby impacting upon both. If corruption is countered by the WTO as a tool to achieving nondiscriminatory trade, that organization could play a role in support human rights (or at least in preventing violations of human rights) without opening itself to charges of exceeding its mandate. Similarly, if there is causation between human rights protection and corruption, steps taken by the WTO to improve trade relations through human rights will also be steps against corruption. It is not the protection of human rights or the reduction of corruption for ideological purposes that needs to be the basis for such actions, but either could be the result.

\section{F. Conclusion}

The question of causation between corruption and the protection of human rights is under-researched. While general causation has been implied through deduction from observances of specific causation in the case of corruption's effects on the protection of human rights, there is little research on the general level itself and very little on human rights protection's impacts on corruption. The matter, however, is extremely important in certain cases, given its implications for organizational approaches to corruption-prevention and human rights protection policies.

Causation as an element of legal research can have significant policy implications on some of the most pressing global problems. The example of the World Trade Organization demonstrates that it is causation itself that should determine the tact that the trade regime should take toward corruption and human rights. While the existing 
analyses of corruption's effects on trade (like those of its effects on human rights) are not sufficient to answer the general causation question, there is a clear potential of the results of such studies to form the basis for far-reaching policy changes in the Organization.

Identifying the problem, as this paper does, is only the first step. Following through will require a great effort to carry out the suggested analyses. The next step will be to engage in further discussion of appropriate methodologies to determine causationin-fact between complex social phenomena such as corruption and human rights. Such a method must be forward-looking (to provide for policy prescriptions), flexible (to capture the variety of forms of corruption), and - above all - able to satisfy the intuitions of members of society that can recognize the impacts of corruption on human rights and human rights on corruption in the midst of the myriad of causal relationships encountered in daily life. 